\title{
KEPERCAYAAN DIRI DITINJAU DARI DUKUNGAN SOSIAL PADA PENYANDANG TUNA NETRA
}

\section{SELF-CONFIDENCE VIEWED FROM SOCIAL SUPPORT IN BLIND PEOPLE}

\author{
Oleh: \\ Hirmar Waki Omnihara Siregar ${ }^{1}$ \\ Winida Marpaung ${ }^{2}$ \\ Rina Mirza ${ }^{3}$
}

\begin{abstract}
Submitted:

26 Maret 2019

This study aims to determine the relationship between social support

Revision:

27 Maret 2019

29 Maret 2019

12 Juni 2019

Accepted:

25 Juni 2019 and self-confidence. The research subjects used in this study were blind persons in the North Sumatra Indonesian Blind Association (PERTUNI) of 150 people who were selected using purposive sampling. Analysis of the data used is to use Product Moment Analysis through SPSS 17 for Windows. The results of data analysis showed $r=0.598$, and $p=0.000(p<0.05)$ which indicates that there is a positive relationship between social support and selfconfidence. The results of this study indicate that the contribution (R2) given the variable social support for self-confidence is equal to 35.7 percent, the remaining 64.3 percent is influenced by other factors not examined. From the results of this study it can be concluded that there is a positive relationship between social support and self-confidence, assuming the higher social support, the higher self-confidence and vice versa the lower the social support, the lower self-confidence.
\end{abstract}

Keywords: Self-Confidence; Social Support; Blind People.

\begin{abstract}
ABSTRAK
Penelitian ini bertujuan untuk mengetahui hubungan antara dukungan sosial dan kepercayaan diri. Subjek penelitian yang digunakan dalam penelitian ini adalah penyandang tuna netra di Persatuan Tuna Netra Indonesia (PERTUNI) Sumatera Utara sebanyak 150 orang yang dipilih dengan menggunakan purposive sampling. Analisis data yang digunakan adalah menggunakan Analisa Product Moment melalui bantuan SPSS 17 for Windows. Hasil analisis data menunjukkan $r=0.598$, dan $\mathrm{p}=$ $0.000(\mathrm{p}<0.05)$ yang menunjukkan bahwa terdapat hubungan positif antara dukungan sosial dan kepercayaan diri. Hasil penelitian ini menunjukkan bahwa sumbangan $\left(\mathrm{R}^{2}\right)$ yang diberikan variabel dukungan sosial terhadap kepercayaan diri adalah sebesar 35.7 persen, selebihnya 64.3 persen dipengaruhi oleh faktor lain yang tidak diteliti. Hasil penelitian ini dapat ditarik kesimpulan bahwa ada hubungan positif antara dukungan sosial dan kepercayaan diri, dengan asumsi semakin tinggi dukungan sosial maka semakin tinggi kepercayaan diri dan sebaliknya semakin rendah dukungan sosial maka semakin rendah kepercayaan diri.
\end{abstract}

Kata Kunci: Kepercayaan Diri; Dukungan Sosial; Penyandang Tuna Netra.

\footnotetext{
${ }^{1}$ Fakultas Psikologi Universitas Prima Indonesia, Email : wakisinzagi@ gmail.com

${ }^{2}$ Fakultas Psikologi Universitas Prima Indonesia, Email : winida.marpaung@ gmail.com

${ }^{3}$ Fakutas Psikologi Universitas Prima Indonesia, Email : rinamirza.psi@ gmail.com
} 


\section{PENDAHULUAN}

Semua manusia menginginkan kesempurnaan pada dirinya, memiliki anggota badan yang lengkap dan mental yang sempurna. Tetapi, kenyataannya tidak semua manusia terlahir sempurna dan mengalami hal yang tidak terduga, bahkan ada juga manusia yang telah lahir sempurna karena penyakit ataupun kecerobohan mereka menjadi tidak sempurna. Ketidak kesempurnaan dari anggota badan ataupun mental yang tidak sempurna sering sekali dikatakan dengan sebutan cacat dan ke cacatan seseorang bahkan sering sekali menjadi bahan ejekan dan cemoohan.

Kecacatan yang dimiliki oleh seseorang menjadi suatu permasalahan yang sangat berat serta dapat menghambat aktivitas mereka dan cita-cita yang ingin mereka capai. Para penyandang cacat sering sekali dititipkan ke panti asuhan karena bagi orangtua mereka sangat menyusahkan. Anak-anak penyandang cacat sering juga disebut sebagai penyandang disabilitas ataupun anak-anak berkebutuhan khusus karena keadaan yang mereka alami (Riyanto, 2013).

Undang-Undang Nomor 8 Ayat 1 pasal 1 (2016, p. 2) menyatakan bahwa:

"Setiap orang yang mengalami keterbatasan fisik, intelektual, mental dan/ atau sensorik dalam jangka waktu lama yang berinteraksi dengan lingkungan dapat mengalami hambatan dan kesulitan untuk berpartisipasi secara penuh dan efektif dengan warga negara lainnya berdasarkan kesamaan hak."

Santoso (2016), menambahkan bahwa Anak Berkebutuhan Khusus dapat dibedakan ke dalam dua kelompok untuk keperluan Pendidikan Luar Biasa, yaitu: Masalah (Problem) dalam Sensorimotor, jenis kelainan yang termasuk kedalam problem dalam sensorimotor yaitu: Hearing disorder (kelainan pendengaran atau tunarungu), Visual Impairment (kelainan penglihatan atau tunanetra), dan Physical Disability (kelainan fisik atau tuna daksa); dan masalah (problem) dalam belajar dan tingkah laku, kelompok Anak Berkebutuhan Khusus yang mengalami problem dalam belajar adalah: Intellectual Disability (keterbelakangan mental atau tunagrahita), Learning disability (ketidakmampuan belajar atau kesulitan belajar khusus), Behavior disorder (anak nakal atau tunalaras), Giftet dan talented (anak berbakat) dan Multy handicap (cacat lebih dari satu atau Tunaganda).

Terkait kelainan penglihatan atau tuna netra ini, Soemantri (2006), menyebutkan bahwa ada dua kelompok kategori tuna netra, yang pertama yaitu buta, dikatakan buta jika anak sama sekali tidak mampu menerima rangsang cahaya dari luar (visusnya $=0$ ); dan yang kedua yaitu Low Vision, bila anak masih mampu menerima rangsang cahaya dari luar, tetapi ketajamannya lebih dari 6/21, atau jika anak hanya mampu membaca headline pada surat kabar.

Ada beberapa masalah terkait penyandang tuna netra, salah satunya seperti yang diutarakan oleh Ketua Persatuan Tuna Netra Indonesia (Pertuni) Ismail Prawira Kusuma mengatakan bahwa penghambat tercapainya kehidupan bermasyarakat secara aktif adalah anggapan tunanetra itu sama dengan sakit. Menurutnya perlakuan yang diberikan kepada para tuna netra menjadi penghalang bagi peyandang tuna netra karena membuatnya dianggap lemah, tidak berdaya dan perlu dikasihani (www.sindonews.com)

Kasus yang sama juga terjadi pada penyandang tuna netra yang berada dibawah naungan Persatuan Tuna Netra Indonesia (Pertuni). Berdasarkan wawancara terhadap 5 orangp enyandang tuna netra, diperoleh hasil bahwa mereka merasa malu dengan kondisi mereka saat ini. Hal ini juga terlihat selama proses wawancara, mereka terlihat malu-malu ketika diwawancarai. Mereka juga mengatakan bahwa tidak sedikit orang yang mengejek terhadap kekurangan yang mereka miliki bahkan pada saat diadakan tugas kelompok disekolah, mereka 
hanya dicantumkan namanya saja dan tidak diperbolehkan ikut bekerja karena teman-teman mereka tidak percaya kepada mereka melihat kekurangan fisik yang dimiliki. Kendala lain yang mereka hadapi, pada saat naik kendaraan umum (becak). Tidak sedikit pengemudi becak yang tidak mau mengantar mereka karena mereka tuna netra, hal ini membuat mereka sedih dan menjadi malu.

Anthony (dalam Ghufron\& Risnawita, 2010), menyatakan bahwa kepercayaan diri merupakan sikap pada diri seseorang yang dapat menerima kenyataan, dapat mengembangkan kesadaran diri, berpikir positif, memiliki kemandirian, dan mempunyai kemampuan untuk memiliki serta mencapai segala sesuatu yang diinginkan.

Hakim (2005) kepercayaan diri adalah sebuah sikap dan prilaku yang terpuji yang harus di miliki oleh setiap orang. Seorang yang percaya diri tentu akan yakin terhadap kemampuan dirinya, sehingga ia berani mengeluarkan pendapat dan berani pula melakukan suatu tindakan.

Menurut Kurama (dalam Hidayat \& Bashori, 2016), terdapat empat aspek kepercayaan diri, yaitu: (a) Kemampuan menghadapi masalah, suatu aktivitas intelektual untuk mencari penyelesaian masalah yang dihadapi dengan menggunakan pengetahuan yang sudah dimiliki; (b) Bertanggung jawab, bertanggung jawab terhadap keputusan dan tindakannya, menerima keputusan dengan penuh tanggung jawab; (c) Kemampuan dalam bergaul, suatu proses kemampuan dalam interaksi sosial yang terjalin antar individu dalam lingkungan sosialnya; (d) Kemampuan menerima kritik, kemampuan seorang dalam menerima, mengolah, dan menyikapi kritikan pihak lain dengan lapang dada.

Angelis (dalam Hidayat \& Bashori, 2016), mengatakan orang yang percaya diri memiliki ciri, yakni: kemampuan diri sendiri dalam melakukan sesuatu, kemampuan untuk menindak lanjuti segala prakasa yang diinisiasinya secara konsekuen, kemampuan pribadi dalam menanggulangi segala kendala, kemampuan individu untuk memperoleh bantuan.

Fatimah (2006), terdapat tujuh karakteristik individu yang mempunyai rasa percaya diri, yaitu: (a) Percaya akan kompetensi/ kemampuan diri, hingga tidak membutuhkan pujian, pengakuan, penerima, ataupun hormat orang lain; (b) Tidak terdorong menunjukkan sikap konformis demi diterima oleh orang lain atau kelompok; (c) Berani menerima dan menghadapi penolakan orang lain- berani menjadi diri sendiri; (d) Punya kendali diri yang baik (tidak moody dan emosinya stabil); (e) Memiliki internal locus of control (memandang keberhasilan atau kegagalan, bergantung pada usaha diri sendiri dan tidak mudah menyerah pada nasib atau keadaan serta tidak bergantung/ mengharapkam bantuan orang lain); (f) Mempunyai cara pandang yang positif terhadap diri sendiri, orang lain, dan situasi di luar dirinya; (g) Memiliki harapan yang realistik terhadap diri sendiri, sehingga ketika harapan itu tidak terwujud, ia tetap mampu melihat sisi positif dirinya dan situasi yang terjadi.

Menurut Mildawani (2014), ada faktor lain yang mempengaruhi kepercayaan diri dapat dibagi menjadi dua faktor. Faktor pertama adalah faktor internal meliputi: Konsep diri, yaitu terbentuknya kepercayaan diri pada seseorang diawali dengan perkembangan konsep diri yang diperoleh dalam pergaulan suatu kelompok; Harga diri, yaitu penilaian yang dilakukan terhadap diri sendiri; Kondisi fisik yaitu, perubahan kondisi fisik juga berpengaruh pada kepercayaan diri. Penampilan fisik bisa menjadi penyebab utama rendahnya harga diri dan rasa percaya diri seseorang; dan pengalaman hidup, pengalaman hidup yang mengecewakan paling sering menjadi sumber timbulnya rasa rendah diri. Faktor kedua adalah faktor eksternal meliputi: pendidikan, tingkah pendidikan yang rendah cenderung membuat individu lebih rendah dari orang pandai. Sebaliknya individu yang pendidikannya lebih tinggi cenderung akan menjadi mandiri dan tidak perlu bergantung pada individu lain; pekerjaan, bekerja dapat mengembangkan kreativitas dan kemandirian serta rasa percaya diri; dan lingkungan dan pengalaman hidup. Lingkungan disini merupakan lingkungan keluarga dan masyarakat. 
Dukungan yang baik yang diterima dari lingkungan keluarga seperti anggota keluarga yang saling berinteraksi dengan baik akan memberi rasa nyaman dan percaya diri yang tinggi.

Salah satu faktor yang mempengaruhi kepercayaan diri adalah dukungan sosial. Sebagaimana penelitian yang dilakukan Jarmitia, dkk., (2016) yang berjudul hubungan antara dukungan sosial dengan kepercayaan diri pada penyandang disabilitas fisik di SLB Kota Banda Aceh. Hasil penelitian menunjukkan bahwa terdapat hubungan yang positif dan signifikan antara dukungan sosial dengan kepercayaan diri pada penyandang disabilitas fisik di SLB Kota Banda Aceh, semakin tinggi dukungan sosial, maka kepercayaan diri pada penyandang disabilitas di SLB Kota Banda Aceh semakin tinggi.

King (dalam Sobur, 2016), mendefenisikan dukungan sosial adalah informasi dan umpan balik dari orang lain yang menunjukkan bahwa seseorang dicintai dan diperhatikan, dihargai, dan dihormati, dan dilibatkan dalam jaringan komunikasi dan kewajiban yang timbal balik. Sarason (dalam Tumanggor dkk., 2010), yang mengakatakan bahwa dukungan sosial adalah keberadaan, kesediaan, kepedulian dari orang-orang yang dapat diandalkan, menghargai dan menyayangi kita

House (dalam Nursalam \& Kurniawati, 2007), menyatakan ada empat jenis dimensi dukungan sosial, yaitu: (a) Dukungan emosional, mencakup ungkapan empati, kepedulian, dan perhatian, terhadap orang yang bersangkutan; (b) Dukungan penghargaan, terjadi lewat ungkapan hormat/penghargaan positif untuk orang lain itu, dorongan maju atau persetujuan dengan gagasan atau perasaan individu, dan perbandingan positif orang itu dengan orang lain, misalnya orang itu kurang mampu atau lebih buruk keadaannya (menambah harga diri); (c) Dukungan Instrumental, mencakup bantuan langsung, misalnya orang memberi pinjaman uang kepada orang yang membutuhkan atau menolong dengan memberi pekerjaan pada orang yang tidak punya pekerjaan; (d) Dukungan informatif, mencakup memberi nasihat, saran, pengetahuan, dan informasi serta petunjuk.

Sarafino dan Smit (2011), menyatakan ada beberapa jenis dukungan sosial, yaitu sebagai berikut: (a) Dukungan penghargaan, dukungan ini dapat berupa penghargaan positif kepada orang lain, mendorong dan memberikan persetujuan atas ide-ide individu atau perasaannya, memberikan semangat, dan membandingkan orang tersebut secara positif. Individu memiliki seseorang yang dapat diajak bicara tentang masalah mereka. Dukungan ini ditandai dengan pernyataan terhadap individu bahwa dia dihargai dan diterima apa adanya; (b) Dukungan emosional, dukungan emosional merupakan dukungan yang berhubungan dengan hal yang bersifat emosional atau menjaga keadaan emosi, afeksi atau ekspresi. Dukungan ini meliputi ekspresi empati, kepedulian, dan perhatian pada individu, memberikan rasa nyaman, memiliki dan perasaan dicintai. Tipe dukungan ini lebih mengacu pada pemberian semangat, kehangatan, cinta kasih dan emosi. Selain ini dukungan ini melibatkan perhatian, rasa percaya dan empati sehingga individu merasa berharga. Dukungan ini sangat penting dalam menghadapi keadaan yang dianggap tidak dapat dikontrol; (c) Dukungan instrumental, dukungan ini merupakan pemberian sesuatu berupa bantuan nyata (tangibleaid) atau dukungan alat (instrumental aid). Dukungan ini meliputi banyak aktivitas seperti menyediakan bantuan dalam pekerjaan rumah tangga, menjaga anak-anak, meminjamkan uang, menyampaikan pesan, menyediakan benda-benda seperti perabot, alat-alat kerja dan buku-buku dukungan ini sangat diperlukan dalam menghadapi keadaan yang dianggap dapat dikontrol; (d) Dukungan informasi, dukungan informasi berarti memberi solusi pada suatu masalah. Dukungan ini diberikan dengan cara menyediakan informasi, memberikan saran secara langsung, atau umpan balik tentang kondisi individu dan apa yang harus dilakukan. Dukungan ini dapat membantu individu mengenali masalah yang sebenarnya. Dukungan informasi berarti memberi solusi pada suatu masalah, memberi nasehat, penghargaan, saran atau feedback mengenai yang telah dilakukan seseorang; (e) Dukungan jaringan, merupakan perasaan individu sebagai bagian dari kelompok. Dukungan ini dapat berupa menghabiskan waktu bersama dengan orang lain dalam 
aktivitas rekreasional di waktu senggang. Serta dukungan ini juga dapat diberikan dalam bentuk menemani seseorang istirahat atau rekreasi. Dukungan ini dapat mengurangi stres dengan memenuhi kebutuhan afiliasi dan kontak dengan orang lain, membantu mengalihkan perhatian dari masalah yang mengganggu serta memfasilitasi suatu suasana hati yang positif.

Tujuan penelitian ini untuk mengetahui kepercayaan diri penyandang tuna netra ditinjau dari dukungan sosial

\section{METODE}

Variabel yang terlibat pada penelitian ini adalah dukungan sosial sebagai variable bebas dan dukungan sosial sebagai variabel terikat. Subjek dalam penelitian ini adalah 105 orang penyandang tuna netra yang menjadi anggota di dalam PERTUNI Sumatera Utara. Teknik pengambilan sampel yang digunakan untuk penelitian ini adalah purposive sampling.

Metode pengumpulan data yang digunakan dalam penelitian ini menggunakan metode pembagian skala untuk mengukur kepercayaan diri dan dukungan sosial. Jenis skala yang digunakan adalah skala Likert.

Skala kepercayaan diri dalam penelitian ini disusun berdarkan aspek-aspek yang dikemukakan oleh Kumara (dalam Hidayat \& Bashori, 2016) yaitu: kemampuan menghadapi masalah, bertanggung jawab, kemampuan dalam bergaul dan kemampuan menerima kritik. Skala kepercayaan diri berjumlah 48 aitem dengan daya gerak dari 0,301-0,585 dengan estimasi reliabilitas Alpha sebesar 0,874. Skala dukungan sosial dalam penelitian ini disusun berdasarkan dimensi yang dikemukakan oleh House (dalam Nursalam \& Kurniawati, 2007) menyatakan ada empat jenis dimensi dukungan sosial, yaitu: dukungan emosional, dukungan penghargaan, dukungan instrumental dan dukungan informatif. Skala dukungan sosial berjumlah 40 aitem dengan daya gerak dari 0,305-0,628 dengan estimasi reliabilitas Alpha sebesar 0,915 .

Teknik analisis yang digunakan untuk menguji hipotesis sekaligus menganalisis data hasil penelitian ini adalah dengan menggunakan metode korelasi Product Moment (Pearson Corellation).

\section{HASIL}

Analisis data dilakukan dengan menggunakan SPSS 17 for windows. Sebelumnya dilakukan uji asumsi yang berupa uji normalitas data dan uji liniearitas.

Tabel 1.

Hasil Uji Normalitas

\begin{tabular}{lccccc}
\hline \multicolumn{1}{c}{ Variabel } & Mean & $\begin{array}{l}\text { Standar } \\
\text { Deviasi }\end{array}$ & KS-Z & Sig & Keterangan \\
\hline $\begin{array}{l}\text { Kepercayaan } \\
\text { Diri }\end{array}$ & 136,73 & 15,154 & 1,016 & $0,254>0,05$ & Normal \\
\hline $\begin{array}{l}\text { Dukungan } \\
\text { Sosial }\end{array}$ & 120,39 & 16,024 & 0,764 & $0,604>0,05$ & Normal \\
\hline
\end{tabular}


Uji normalitas dilakukan agar dapat mengetahui apakah setiap variabel penelitian telah menyebar secara normal atau tidak. Uji normalitas sebaran menggunakan uji Kolmogorov Smirnov Test. Data dikatakan berdistribusi normal jika $\mathrm{p}>0.05$ (Priyatno, 2010). Uji normalitas yang dilakukan terhadap variabel intensi kepercayaan diridiperoleh koefisien KS-Z $=1.016$ dengan Sig sebesar 0.254 untuk uji 2 (dua) arah dan Sig sebesar 0.127 untuk uji 1 (satu) arah ( $\mathrm{p}>0.05)$, yang berarti bahwa data pada variabel kepercayaan diri memiliki sebaran atau berdistribusi normal. Uji normalitas pada variabel dukungan sosial diperoleh koefisien KS-Z = 0.764 dengan Sig sebesar 0.604 untuk uji 2 (dua) arah dan Sig sebesar 0.302 untuk uji 1 (satu) arah ( $\mathrm{p}>0.05)$, yang berarti bahwa data pada variabel dukungan sosial memiliki sebaran atau berdistribusi normal.

Tabel 2.

Hasil Uji Linearitas Hubungan

\begin{tabular}{lccl}
\hline Variabel & F & Sig & Keterangan \\
\hline kepercayaan diri & & & \\
dukungan sosial & 89,138 & 0,000 & Linear \\
\hline
\end{tabular}

Berdasarkan tabel 2. dapat dikatakan bahwa variabel kepercayaan diri dan dukungan sosialmemiliki hubungan linear. Hal ini terlihat dari nilai sig yang diperoleh yaitu 0.000 maka $\mathrm{p}<0.05$, dapat disimpulkan bahwa kedua variabel memiliki hubungan linear dan telah memenuhi syarat untuk dilakukan analisa korelasi Product Moment.

Hasil penelitian pada 150 penyandang tuna netra di PERTUNI Sumatera Utara yang menjadi subjek penelitian, diperoleh hasil bahwa ada hubungan antara dukungan sosial dengan kepercayaan diridengan koefisien korelasi Product Moment sebesar $\mathrm{r}=0.598$ dan nilai $\mathrm{p}=$ 0.000, artinya semakin tinggi dukungan sosial maka semakin tinggi kepercayaan diri, dan sebaliknya semakin rendah dukungan sosial maka semakin rendah kepercayaan diri.

Pada penelitian ini diperoleh koefisien determinasi $R$ Square $\left(\mathrm{R}^{2}\right)$ sebesar 0.357 . Berdasarkan hasil tersebut, dapat disimpulkan bahwa 35.7 persen dukungan sosial mempengaruhi kepercayaan diri, sedangkan 44.3 persen dipengaruhi oleh faktor lain. Adapun faktor lain yang turut mempengaruhi kepercayaan diri diantaranya, seperti kemampuan menghadapi masalah, bertanggung jawab, kemampuan dalam bergaul, dan kemampuan menerima kritik.

Untuk melakukan sesuatu, seorang individu harus mempunyai kepercayaan terhadap dirinya sendiri untuk menyelesaikan ataupun menjalani suatu hal baik dengan fisik yang sempurna maupun tidak. Kepercayaan diri merupakan suatu keyakinan yang dimiliki seseorang bahwa dirinya mampu memperoleh hasil seperti yang diharapkan (Bandura dalam Sudarjo \& Purnamaningsih, 2003)

Terkait hal tersebut, Semiun (2006) menyebutkan bahwa adapun dukungan kelompok untuk tingkah laku yang tepat, para pasien mungkin mengharapkan terapis mendukung mereka, tetapi dukungan yang diberikan oleh kawan-kawan sekelompok mungkin memiliki pengaruh yang lebih besar terhadap peningkatan harga diri dan kepercayaan diri.

\section{PEMBAHASAN}

Hasil penelitian pada 150 penyandang tuna netra di PERTUNI Sumatera Utara yang menjadi subjek penelitian, diperoleh hasil bahwa ada hubungan antara dukungan sosial dengan kepercayaan diridengan koefisien korelasi Product Moment sebesar $\mathrm{r}=0.598$ dan nilai $\mathrm{p}=$ 
0.000, artinya semakin tinggi dukungan sosial maka semakin tinggi kepercayaan diri, dan sebaliknya semakin rendah dukungan sosial maka semakin rendah kepercayaan diri.

Adapun hasil penelitian ini juga sejalan dengan penelitian yang dilakukan oleh beberapa peneliti lain. Hal ini diperkuat dengan penelitian yang dilakukan oleh Sakti dan Rozali (2015) terhadap 117 Atlet Atlet Taekwando Club BJTC menunjukkan adanya hubungan antara dukungan sosial dengan kepercayaan diri. Hasil menunjukkan bahwa dukungan sosial memiliki korelasi positif dan signifikan dengan kepercayaan diri.

Pada penelitian ini diperoleh koefisien determinasi $R$ Square $\left(\mathrm{R}^{2}\right)$ sebesar $0 . .357$. Berdasarkan hasil tersebut, dapat disimpulkan bahwa 35.7 persen dukungan sosial mempengaruhi kepercayaan diri, sedangkan 44.3 persen dipengaruhi oleh faktor lain. Adapun faktor lain yang turut mempengaruhi kepercayaan diri diantaranya, seperti kemampuan menghadapi masalah, bertanggung jawab, kemampuan dalam bergaul, dan kemampuan menerima kritik.

Penelitian ini menunjukkan rata-rata penyandang tuna netra yang berada di PERTUNI Sumatera Utara memiliki kepercayaan diri yang sedang yang dapat dilihat dari data penelitian terdapat 58 orang atau 38 persen penyandang tuna netra berada di kategori tinggi, kemudian terdapat 90 orang atau 60 persen penyandang tuna netra berada di kategori sedang dan terdapat 2 orang atau 2 persen penyandang tuna netra berada di kategori rendah. Berdasarkan penjelasan diatas dapat disimpulkan rata-rata penyandang tuna netra di PERTUNI Sumatera Utara memiliki kepercayaan diri yang sedang.

Berdasarkan hasil observasi dan wawancara terdapat sebanyak 58 orang penyandang tuna netra di PERTUNI Sumatera Utara dengan persentase 38 persen menunjukkan tingkat kepercayaan diri yang tinggi. Diketahui bahwa mereka di lingkungan tempat tinggal lebih banyak berinteraksi dan keluarga bahkan orang-orang disekitarmereka lebih sering memberikan motivasi dan mereka berpikir bahwasannya keterbatasan bukan akhir dari segalanya dan mereka dapat menerima dengan baik kekurangan yang dimiliki. Pernyataan diatas sejalan dengan aspek dari kepercayaan diri, yaitu kemampuan dalam bergaul yang merupakan interaksi sosial yang terjalin antara individu dengan lingkungannya.

Sebanyak 90 orang penyandang tuna netra di PERTUNI Sumatera Utara dengan persentase 60 persen memiliki tingkat kepercayaan diri yang sedang. Hasil dari wawancara menunjukkan mereka masih banyak yang belum mampu bergaul dengan sepenuhnya dan masih malu-malu karena masih ada sedikit rasa minder dan tidak nyaman dengan teman lainnya, takut menjadi beban untuk orang lain. Pada saat mereka diberikan masukan oleh orang lain mereka sudah lebih dapat menerima masukan tersebut untuk membuat diri menjadi lebih baik lagi. Selain, itu beberapa orang juga mengatakan ketika mereka mengalami masalah, mereka menyelesaikan dalam jangka waktu yang lama hingga masalah tersebut selesai karena dipengaruhi oleh keterbatasan mereka.Pernyataan diatas sesuai dengan aspek kepercayaan diri, yaitu kemampuan menerima kritik dan saran dimana mereka sudah lebih mampu untuk menerima kritik dan saran dari orang lain, walaupun terkadang masih tidak nyaman dan sulit menerima kritikan tersebut.

Terdapat pula 2 orang penyandang tuna netra di PERTUNI Sumatera Utara yang memiliki tingkat kepercayaan diri rendah dengan persentase 2 persen. Dari hasil wawancara didapatkan bahwasannya mereka khawatir kalau mereka tidak dapat berguna bagi orang lain. Kekurangan mereka membuat orang lain dan teman-teman menjauh, mereka juga sering diejek karena kekurangan yang dimiliki, mereka juga merasa bahwa diri mereka mengganggu kehidupan orang lain karena belum dapat melakukan suatu hal secara mandiri. Situasi ini membuat mereka hanya dapat pasrah dengan kehidupan mereka. Motivasi yang mereka dapatkan juga sangat sedikit dan ketika mereka mendapatkan suatu masalah mereka sangat 
sulit untuk menyelesaikannya, mereka juga rentan tersinggung dengan masukan yang diberikan orang lain. Ini sangat bertolak belakang dengan aspek kepercayaan diri, yaitu kemampuan menghadapi masalah, kemampuan dalam bergaul dan kemampuan menerima kririk dan saran.

Penelitian ini juga meneliti mengenai dukungan sosial yang diterima oleh penyandang tuna netra di PERTUNI Sumatera Utara. Sebanyak 81 orang atau 54 persen penyandang tuna netra berada di kategori tinggi, 68 orang atau 45 persen penyandang tuna netra berada di kategori sedang, sedangkan sisanya 1 orang atau 1 persen berada di kategori rendah. Jadi, dapat disimpulkan bahwa rata-rata penyandang tuna netra di PERTUNI Sumatera Utara memilikir dukungan sosial tergolong tinggi.

Penelitian ini mendapatkan sumbangan tertinggi dalam dukungan sosial sebanyak 81 dengan persentase 54 persen. Orang yang tergolong memiliki dukungan sosial yang tinggi, mereka merasa dukungan yang diberikan oleh orang-orang sekeliling, seperti teman-teman atau keluarga selalu memberikan dukungan yang membangun, seperti memberi saran, rasa saying, dukungan secara moral, material dan juga kasih sayang dari orang tua.

Sebanyak 68 orang penyandang tuna netra di PERTUNI Sumatera Utara atau 45 persen memiliki tingkat dukungan sosial dalam kategori sedang. Dalam hal ini penyandang tuna netra masih mendapat dukungan dari keluarga dan juga orang-orang terdekat, seperti teman-teman mereka. Mereka menuturkan, mereka juga mendapat perhatian dan kepedulian, pendapat mereka dihargai dan kebutuhan untuk sekolah terpenuhi. Selain itumerka juga mengatakan ada beberapa teman-temannya yang memiliki kondisi sehat kurang menghargai pendapat mereka, kurang berempati serta kurang peduli kepada mereka merekamengatakan dukungan yang mereka terima tidak sangat banyak dan tidak sedikit, tetapi dalam kategori sedang.

Selain hal tersebut, terdapat juga penyandang tuna netra yang tergolong dalam kategori rendah, yaitu sebanyak 1 orang atau 1 persen. Penyandang tersebut menuturkan dia tidak mendapatkan dukungan yang seharusnya ia terima, karena salah satu factor menurut beliau karena ia tinggal jauh dari keluarga dan sangat jarang bertemu dengan keluarganya, beliau menuturkan sering sekali mendapatkan ejekandari teman serta tidak mendukung apa yang dilakukan oleh temannya.

Berdasarkan uraian diatas, maka dapat disimpiulkan bahwa seseorang yang memiliki kepercayaan diri yang tinggi dipengaruhi oleh faktor dukungan sosial yang tinggi juga sehingga muncul suatu hubungan yang ada, jika seseorang menerima dukungan sosial yang rendah maka kepercayaan diri pada diri seseorang tersbut akan menjadi lemah juga. Penjelasan diatas menunjukkan adanya hubungan positif antara kepercayaan diri dengan dukungan sosial. Jika seorang penyandang tunannetra menerima dukungan sosial yang tinggi maka kepercayaan dirinya akan tinggi pula. Sebaliknya, jika dukungan sosial yang diterima rendah maka kepercayaan dirinya akan rendah pula.

\section{KESIMPULAN}

Kesimpulan dari penelitian ini Ada hubungan positif antara dukungan sosial dengan kepercayaan diri pada penyandang tuna netra di Persatuan Tuna Netra Indonesia (PERTUNI) Sumatera Utara, artinya semakin tinggi dukungan sosial yang diterima seseorang maka semakin tinggi pula kepercayaan diri seseorang, dan sebaliknya semakin rendah dukungan sosial yang diterima maka semakin rendah pula kepercayaan diri.

\section{Saran}

Saran bagi penyandang tuna netra diharapkan agar penyandang tuna netra lebih percaya terhadap dirinya sendiri, serta tidak berpikir negative terhadap keadaan dirinya hingga mengakibatkan rasa minder jika bertemu dengan orang lain. Saran bagi peneliti selanjutnya 
disarankan dapat meneliti faktor-faktor lainnya seperti dukungan teman sebaya, citra tubuh, penerimaan diri dan obesitas.

\section{DAFTAR PUSTAKA}

Fatimah, E. (2006). Psikologi Perkembangan (Perkembangan Peserta Didik). Bandung: CV Pustaka Setia

Ghufron, M. N. \& Risnawita, R. (2010). Teori-Teori Psikologi. Depok: AR-RUZZ Media.

Hakim, T. (2005). Mengatasi Rasa Tidak Percaya Diri. Depok: Puspa Swara.

Hidayat, K. \& Bashori, K. (2016). Psikologi Sosial. Jakarta: Erlangga.

Jarmitia, S., Sulistyani, A., Yulandari, N., Tatar, F. M., \& Santoso, H. (2016). Hubungan antara Dukungan Sosial dengan Kepercayaan Diri pada Penyandang Disabilitas Fisik di SLB

Kota Banda Aceh. Jurnal Psikoislamedia, 1(1). Diakses pada 30 April 2018 dari eprints.ums.ac.id/48360/34/naskah\%20publikasi.pdf

Kemendagri. (2016). Undang-Undang Pasal 8 pasal 1 ayat 1 Tentang Penyandang Disabilitas. Jakarta: Kemendagri. Diakses pada 4 Mei 2016 dari www.kemendagri.com.

Mildawani. (2014). Membangun Kepercayaan Diri. Jakarta Timur: Lestari Kiranatama.

Nursalam \& Kurniawati, N. D. (2007). Asuhan Keperawatan Pada Pasien Terinfeksi Hiv/Aids. Jakarta: Salemba Medika. Diakses pada 26 April 2018 dari https://books.google.co.id/books?id=LITG5E64XC8C\&pg=PA29\&dq=dukungan+sos ial\&hl=en\&sa=X\&ved=0ahUKEwj19vvOrcbcAhXUbX0KHd6JCPcQ6AEIJzAA\#v=o nepage $\& \mathrm{q}=$ dukungan $\% 20$ sosial $\& \mathrm{f}=$ false

Riyanto, A. (2013). Anak Penyandang Disabilitas. New York: United Nations Children's Fund. Diakses pada tanggal 26 April 2018 dari www.unicef.org.

Sakti, G. F. \& Rozali, Y. A. (2015). Hubungan Dukungan Sosial Dengan Kepercayaan Diri pada Atlet Cabang Olah Raga Taekwando Dalam Berprestasi (Studi pada Atlet Taekwando Club BJTC, Kabupaten Tangeramg). Jakarta: Fakultas Psikologi Universitas Esa Unggul. Jurnal Psikologi,13(1). Diakses pada 23 Maret 2018 dari https://ejournal.undip.ac.id/index.php/psikologi/article/view/692

Santoso, H. (2016). Cara Memahami dan Mendidik Anak Berkebutuhan Khusus. Yogyakarta: Gosyen Publishing.

Sarafino, E. P. \& Smith, T. W. (2011). Healthy Psychology: Biopsychosocial Interaction Sevent Edition. United States of America: Jhon Wiley \& Sons, Inc. Diakses pada 10 April 2018 dari http://gen.lib.rus.ec/search.php?req=Healthy+psychology\&lg_topic= libgen \&open $=0 \&$ view $=$ simple \&res $=25 \&$ pharse $=0 \&$ column $=$ def.

Semiun, Y. (2006). Kesehatan Mental 3. Yogyakarta: Kanisius.

Sobur, A. (2016). Kamus Psikologi. Bandung: CV PUSTAKA SETIA.

Soemantri, T. S. (2006). Psikologi Anak Berkebutuhan Khusus. Bandung: PT. Refika Aditama. Soewadji, J. (2012). Pengantar Metodologi Penelitian. Jakarta: Mitra Wacana.

Sugiyono. (2017). Metode Penelitian Pendidikan (Pendekatan Kuantitatif, Kualitatif, dan $R \& D)$. Bandung: Alfabeta.

Tumanggor, R., Ridho, K., \& Nurrochim. (2010). Ilmu Sosial dan Budaya Dasar Edisi Ketiga. Jakarta: Kencana.

Sindonews.com. (2013). Penyandang tunantera di Indonesia alami diskriminasi. Diakses pada 2 Meil 2018 dari https://nasional.sindonews.com/read/799806/15/penyandangtunanetra-di-indonesia-alami-diskriminasi-1383061850 